\title{
Resistance seam hardfacing and cladding of WC-Co in a NiCrBSi-Matrix
}

\author{
Zgrzewanie rezystancyjne ciągłe kompozytowych \\ powłok ochronnych WC-Co oraz na osnowie NiCrBSi
}

\begin{abstract}
Resistance seam hardfacing is a process to weld thin hardfacing layers. The process is based on resistance seam welding where one joining partner is a metal powder. The aim is the production of low dilution hardfacings on simple shaped structural elements (e.g. bolts). This was investigated by metallography and scanning electrone microscopy. Further the economic efficiency of the prozess was worked out.
\end{abstract}

Keywords: hardfacing; cladding; suface modification; resistance welding

\section{Streszczenie}

Zastosowano zgrzewanie rezystancyjne ciągłe do wytwarzania kompozytowych powłok ochronnych. Specyfika zadania polegała na zgrzewaniu proszku do metalowego podłoża. Uzyskano powłoki ochronne kompozytowe WC -Co oraz na osnowie NiCrBSi z niskim współczynnikiem wymieszania z podłożem. Przeprowadzono analizę struktury uzyskanych powłok z użyciem mikrosopii świetlnej i skaningowej. Dodatkowo przeanalizowano efektywność ekonomiczną procesu

Słowa kluczowe: powłoki kompozytowe; zgrzewanie proszków; modyfikacja powierzchni

\section{Wstęp}

Resistance seam hardfacing is a process to weld thin hardfacing layers. The process is based on resistance seam welding where one joining partner is a metal powder. The aim is the production of low dilution hardfacings on simple shaped structural elements (e.g. bolts). This was investigated by metallography and scanning electrone microscopy. Further the economic efficiency of the prozess was worked out.

\section{Process}

\section{Hardfacing}

The conventional hardfacing works with fusion welding processes, which are classified in EN 14700 [2].

All hardfacing processes in common have the attribute of a dilution level. The dilution level describes the compounding of filler metal and base metal. It should be low to form the desired layer with its conditions. In case of gas metal arc welding it can be up to $50 \%$ and with manual arc welding up to $25 \%$. The dilution level can be calculated:

The hardfacing conditions in a workshop are the same like for other fusions welding processes.

\section{Thermal spraying}

Thermal spraying uses technical gases and an energy source to create thermal and kinetic energy. According to
EN 657 [3] different energy sources can be used. An important need in thermal spraying is the keying of the surface and the activation of the surface by blasting and also the masking and unmasking in pre- and post-treatment. Keying is nessecary to enable a mechanical joint of the sprayed layer. Thermal spraying is made in a special cabin with acoustic protection and extraction. So the invest to save health environment is relatively high.

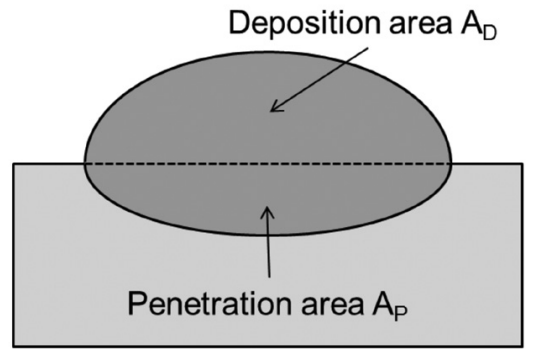

Fig. 1. Areas to calculate the dilution level

Rys. 1. sposób liczenia stopnia wymieszania powłoki z podłożem

\section{Resistance seam hardfacing [4]}

Resistance seam hardfacing is a modified resistance seam welding process, where the joining partners are a metal powder and a structural element instead of two sheet metals. These structural elements are rotationally symmetric workpieces and rotate around their axis, figure 2.

Dipl.-Ing Tobias Broda, Prof. Dr.-Ing. Steffen Keitel - SLV Halle GmbH.

Autor korespondencyjny/Corresponding author. broda@slv-halle.de 


\section{Powder funnel}

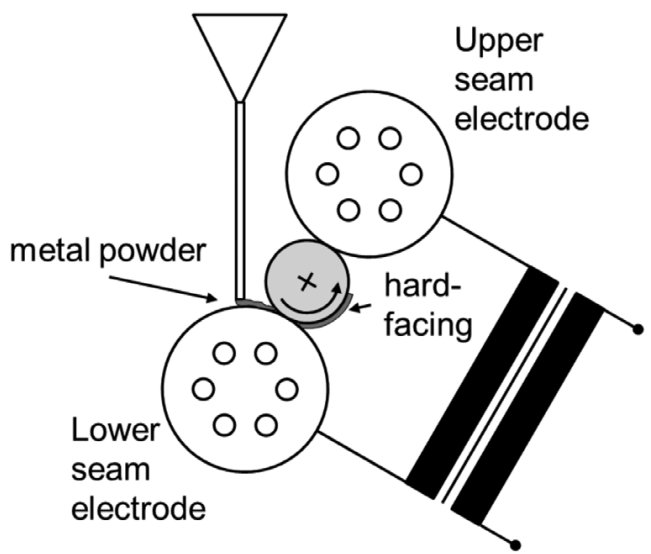

Fig. 2. Scheme of resistance seam hardfacing

Rys. 2. Schemat procesu zgrzewania rezystancyjnego powłok

Two seam electrodes which are connected to the transformer are pressed to the workpiece. The metal powder acts as filler meterial and is dispensed to the lower seam electrode by a powder funnel. The powder is transported to the workpiece by the electrode rotation. The Hardfacing is created by the resistance heating of the powder and workpiece surface by the current flow between the seam electrodes. The lateral surface on the workpieces is formed by a relative movement between the seam electrodes and the workpiece in a spiral shaped way.

Some characteristics of the process are shown in table I.

Table I. Attributes of resistance seam hardfacing Tablica I. Zalety zgrzewania rezystancyjnego powłok

\begin{tabular}{|c|c|c|}
\hline $\begin{array}{l}\text { evaluation } \\
\text { scope }\end{array}$ & $\begin{array}{c}\text { technical } \\
\text { advantages }\end{array}$ & $\begin{array}{l}\text { economical } \\
\text { advantages }\end{array}$ \\
\hline $\begin{array}{l}\text { hardfacing } \\
\text { layer }\end{array}$ & $\begin{array}{l}\text { - high hardness } \\
\text { - oxide free } \\
\text { - low porosity } \\
\text { - excellent joint }\end{array}$ & $\begin{array}{l}\text { lifetime improve- } \\
\text { ment of hardfaced } \\
\text { workpieces up to } \\
>500 \%\end{array}$ \\
\hline $\begin{array}{l}\text { process } \\
\text { technology }\end{array}$ & $\begin{array}{l}\text { - no keying needed } \\
\text { - no masking } \\
\text { - automatable } \\
\text { - no alloy burn-out }\end{array}$ & $\begin{array}{l}\text { - multi machine } \\
\text { operation } \\
\text { - high metal } \\
\text { powder utilization } \\
\text { (powder loss goes } \\
\text { to zero) }\end{array}$ \\
\hline $\begin{array}{l}\text { industrial } \\
\text { safety }\end{array}$ & $\begin{array}{l}\text { - low noise level ( } 65 \mathrm{~dB}) \\
\text { - nearly no pollution }\end{array}$ & $\begin{array}{l}\text { - no acoustic } \\
\text { protection cabin } \\
\text { - no exhaust ven- } \\
\text { tilation } \\
\text { - no glare shield } \\
\text { - no environmen- } \\
\text { tal pollution }\end{array}$ \\
\hline
\end{tabular}

\section{Metal powders}

\section{Tungsten carbides}

As a consequence of the limited performance of specific hard phases like carbides, nitrides, boronides and siliconides in iron-, nickel- and cobalt-based materials, additional hard phases are added. Tungsten carbides are generally accepted in wear protection through its excellent performance. Tungsten carbides are characterized by a high hardness and wear proof. Tungsten carbides are divided in mono tungsten carbides (short WC) and fused tungsten carbides (short FWC). Latter are a compound of Ditungsten carbide
W2C and WC in a small range 3,8 bis 4,2 wt. \% carbon. These compounds can be obtained, if FWC are cooled down rapidly. If FWC are heated up over $1250{ }^{\circ} \mathrm{C}$, it decomposes in W and WC. [5]

\section{Cobalt cemented mono tungsten carbides}

Often tungsten carbides are mixed with cobalt. The powder compound is formed by agglomerating and sintering [6]. These powders are qualified for thermal spraying and are also applied for plasma transfered arc welding (PTA). The powders have 6 to 17 wt. \% of Co and have a hardness of app. 1500 HV. Pure WC has app. 2300 HV. These powders are magnetic.

\section{Self-fluxing nickel alloys}

NiCrBSi-alloys have the feature to create a kind of flux by ist constitutes of boron and silicon. The melt wettens the workpiece surface and is able to reduce residual oxides [1]. The powder is non-magnetic and has good wear and corrosion protection features. Self-fluxing nickel alloys work well as matrix materials, because embraced hardfacing materials were not that damaged (decomposed) during welding like in for example iron matrices [5].

\section{Resistance seam hardfacing on the example of "chain bucket bolts"}

The application relates to lignite mining. Chain bucket excavators are massive conveyors. A chain with buckets on their links is drawn across an acclivity, where overburden is conveyed continuously. The fasteners are hardened bolts made from $58 \mathrm{CrV} 4$, which are exposed to abrasive wear through the bearings of the chain links by redirecting, figure 3 .

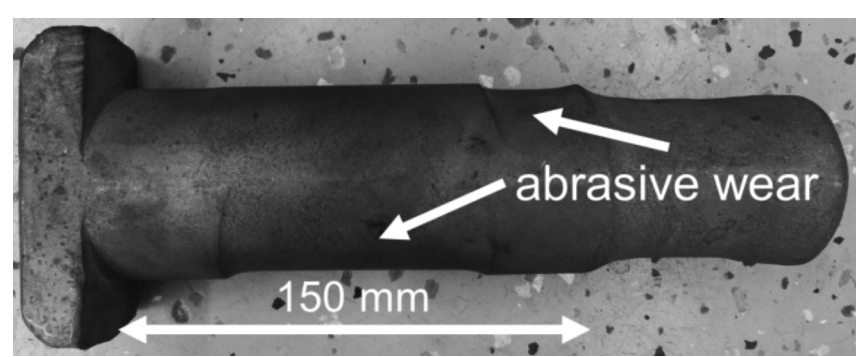

Fig. 3. Abrasive wear on a bucket chain bolt

Rys. 3. Widok zużycia sworznia transportowego łańcucha kubełkowego

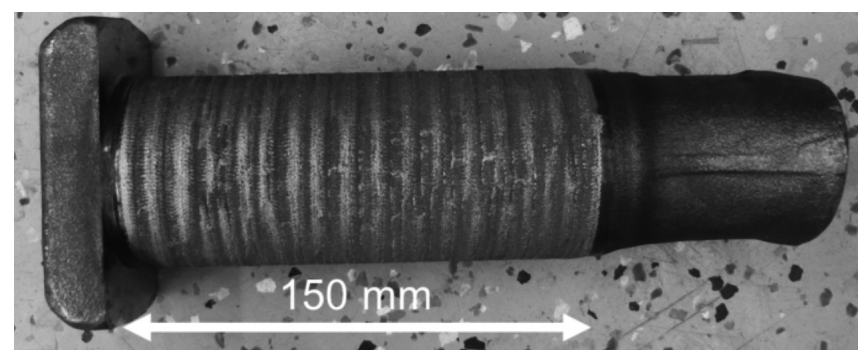

Fig. 4. Bucket chain bolt with NiCrBSi layer (light grey) and WC-Co layer (dark grey)

Rys. 4. Widok sworznia transportowego łańcucha kubełkowego ze zgrzaną powłoką ochronną

A multilayer system is applied to improve the wear resistance. After investigating a lot of metal powders a three layer system was found. It consists of

- NiCrBSi (particle size 45 - $125 \mu \mathrm{m}$ )

- WC-Co (particle size 80 - $200 \mu \mathrm{m}$ )

- NiCrBSi (particle size 45 - $125 \mu \mathrm{m}$ ) 
The first layer of NiCrBSi is used for disoxidation and as matrix layer. The second layer consisting of WC-Co is inserted in the matrix layer and is joined by diffusion (Figure 4). Basically, the wear protection with these two layers would be completed, but the bolts would result bearing wear, which is why again in a third layer NiCrBSi is applied. This raises the corrosion protection, too.

A picture during the resistance seam hardfacing shows figure 5 .

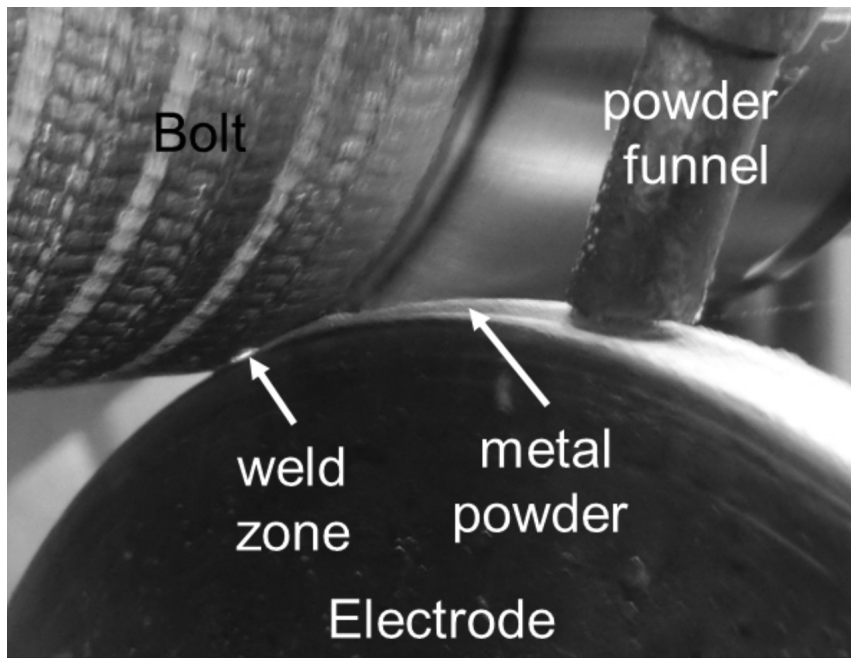

Fig. 5. Rsistance seam hardfacing in process

Rys. 5. Proces zgrzewania ciągłego oporowego powłoki ochronnej

\section{Metallography}

Figure 6 shows the layer structure of the bolts. The hard materials are not dispersed. In particular, the larger WC-Co particles are embedded in their sintered spherical form in the NiCrBSi matrix.

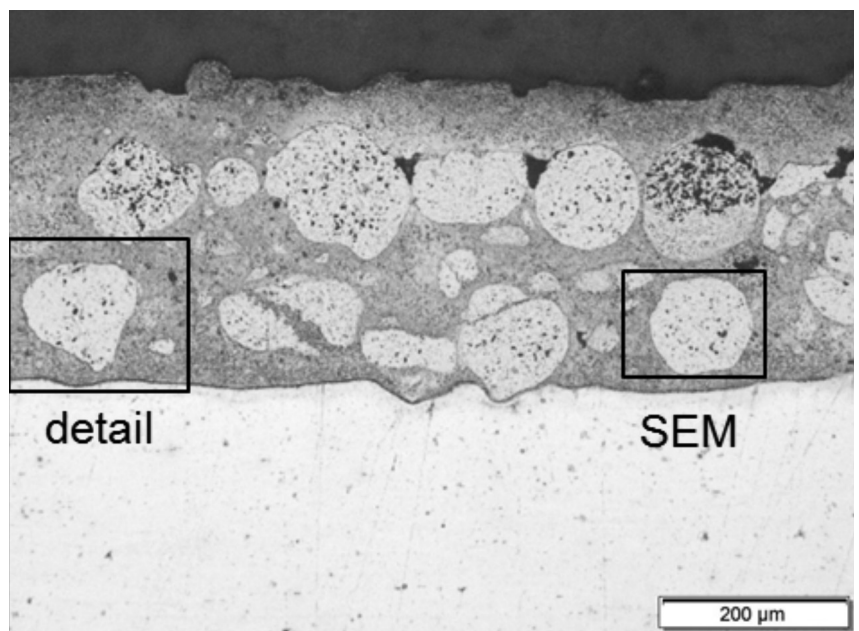

Fig. 6. Multilayer-hardfacing of NiCrBSi and WC-Co

Rys. 6. Wielowarstwowa powłoka ochronna NiCrBSi oraz WC-Co

A detail from figure 6 is shown in figure 7 . The self-fluxing NiCrBSi matrix wets the hard balls, thus ensuring a cohesive connection. In figure 7 it can be seen that smaller WC-Co particles have a much more irregular shape. These dissolve in the matrix.

For the base material, the compound is present on the basis of a narrow diffusion layer. According to figure 1 the dilution level can be calculated. With a total layer thickness of $\mathrm{t}=0.340 \mathrm{~mm}$ and a diffusion layer of $\mathrm{d}=0.003 \mathrm{~mm}$, the dilution level is $\mathrm{D}=1 \%$.
Scanning electron microscopy studies show that the smaller WC-Co balls are dissolved in the matrix (Figure 8). Recognizable is the fine distribution of bright particles. Heavy elements such as tungsten are given bright in SEM. This shows that the smaller hardfacing particles get dissolved in the matrix, the bigger ones are stable.

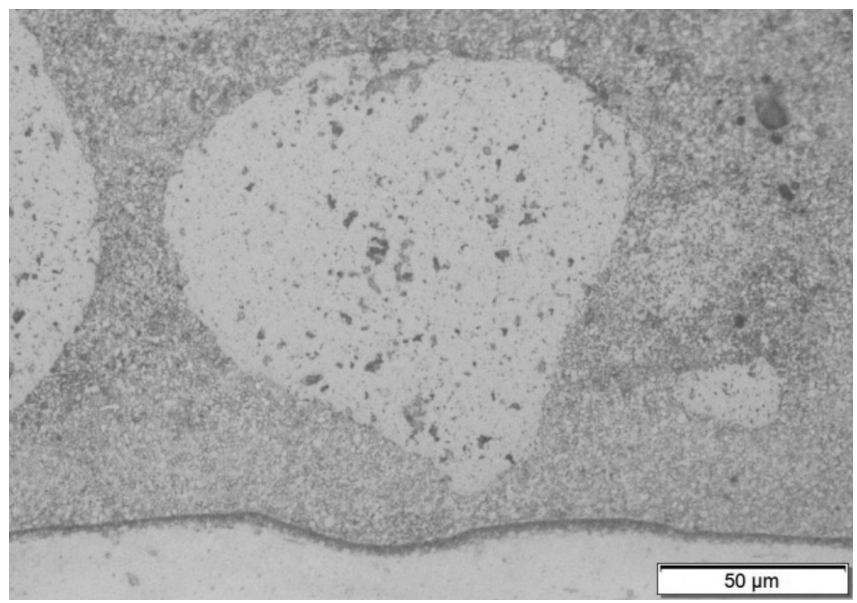

Fig. 7. Bond to basematerial and carbide

Rys. 7. Struktura połączenia osnowy z umocnieniem węglikowym oraz osnowy z podłożem

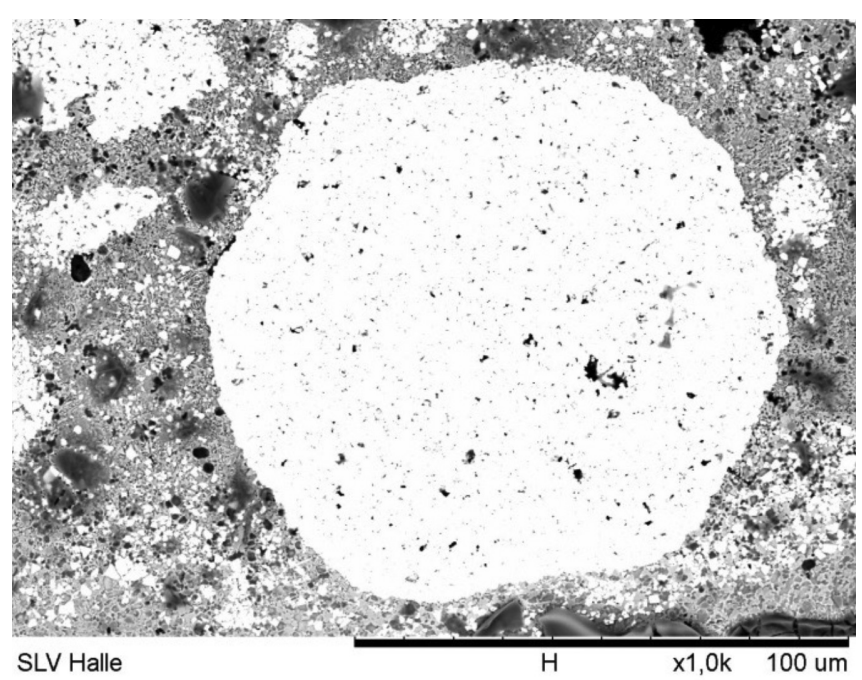

Fig. 8. SEM picture of NiCrBSi-Matrix and WC-Co carbide Rys. 8. Obraz SEM osnowy NiCrBSi oraz WC-Co

The distribution of elements from an EDX revealed that cobalt is excreted in NiCrBSi matrix, while silicon accumulates to WC.

\section{Economy}

In reference to [7] machine hour rates were calculated for resistance seam hardfacing and high velocity flame spraying. While the total cost for a motion system and process-specific modules is approximately equal, see table $\mathrm{I}$, the cost of the spraying technique is more expensive due to the high cost of occupational health and safety so that a ratio of about $3: 2$ is produced to the disadvantage of spraying technology.

Even starker is the difference in the energy and auxiliary costs. Here, the ratio is $5: 1$ to the disadvantage of spray technique. Comparing with bottled oxygen, the ratio is even more unfavorable.

Not to be forgotten are further costs by powder losses 
during spraying. Since the excess powder is not thermally affected during roll seam buildup welding, it is re-used, so that the powder losses are theoretically equal to zero. Here $3 \%$ was expected.

In these approaches, the machine hour rates are:

- Resistance seam hardfacing app. $44 € / h$

- HVOF-Spritzen (with liquid oxigen) app. 100,00 €/h

\section{Outlook}

In future work an efficient design of the plant technology will be achieved, with the application speed to be increased again in favor of the application rate. The aim should be to specialize the component size in the direction of small parts and use new hard facing materials.

Table II. Financial comparison between thermal spraying and resistance seam hardfacing

Tablica II. Porównanie pod względem ekonomicznym powłoki zgrzewanem oporowo i natryskiwanej cieplnie

\begin{tabular}{|c|c|c|c|}
\hline Invest & Thermal spraying & $\begin{array}{l}\text { Resistance seam } \\
\text { hardfacing }\end{array}$ & \\
\hline Movement device & $50.000,00$ & & $€$ \\
\hline Process specific devices & $95.000,00$ & $150.000,00$ & $€$ \\
\hline Cooling system & $12.500,00$ & $5.000,00$ & $€$ \\
\hline Acoustic protection cabin & $40.000,00$ & & $€$ \\
\hline Suction system & $40.000,00$ & & $€$ \\
\hline Packing, transport, set-up & $10.000,00$ & $20.000,00$ & $€$ \\
\hline Total cost & $250.000,00$ & $187.500,00$ & $€$ \\
\hline
\end{tabular}

Calculation of machine rate (single shift)

\begin{tabular}{|c|c|c|c|}
\hline Amortization 6 years ${ }^{1)}$ & 32,55 & 24,41 & $€ / h$ \\
\hline Calculated interes (12\% invest/2) ${ }^{1)}$ & 11,72 & 8,79 & $€ / h$ \\
\hline Room cost (100 $\mathrm{m}^{2}$ each $4,00 € /$ month $)^{1)}$ & 3,75 & 3,75 & $€ / h$ \\
\hline Maintenace cost ( $2 \%$ of invest $)^{1)}$ & 3,91 & 2,93 & $€ / h$ \\
\hline Rental oxygen vaporiser $\left.{ }^{2}\right)$ & 4,69 & & $€ / h$ \\
\hline
\end{tabular}

\section{Operation cost}

\begin{tabular}{|c|c|c|c|c|}
\hline Power of movement device & \multicolumn{2}{|c|}{2} & 2 & $\mathrm{~kW}$ \\
\hline Power cooling system & \multicolumn{2}{|c|}{12} & 5 & $\mathrm{~kW}$ \\
\hline Process specific power & \multicolumn{2}{|c|}{0,00} & 10 & $\mathrm{~kW}$ \\
\hline Power cost at $0,15 € / \mathrm{kWh}$ & 2,10 & 2,10 & 2,55 & $€ / h$ \\
\hline $\mathrm{N} 2 \quad 12 \mathrm{l} / \mathrm{h}$ & 0,12 & 0,12 & & $€ / h$ \\
\hline Kerosine $\quad 20 \mathrm{l} / \mathrm{h}$ & 10,00 & 10,00 & & $€ / h$ \\
\hline Consumables cost ${ }^{1)}$ & 1,00 & 1,00 & 1 & $€ / h$ \\
\hline Powder loss ${ }^{4)}$ & 20,00 & 20,00 & 0,36 & $€ / h$ \\
\hline Machine cost rate & 101.83 & 209,83 & 43,79 & $€ / h$ \\
\hline \multicolumn{5}{|c|}{$\begin{array}{l}\text { 1) Based on DVS-Merkblatt } 3211 \text {, assumptior } \\
\text { 2) Rental für vaporiser per month = } 500 € \\
\text { 3) } 1 \mathrm{~m}^{3} \text { liquid oxygen - 0,20 } € ; 1 \text { bottle oxygen } \\
\text { 4) Assumption: powder cost } 40,00 € / \mathrm{kg} \\
\text { - thermal spray conditions: - rate } 1 \mathrm{~kg} / \mathrm{h} \\
\text { - loss } 50 \% \\
\text { - resistance seam hardfacing: - rate } 0,3 \mathrm{~kg} / \mathrm{h} \\
\text { - loss } 3 \% \\
\text { * Cost incl. movement device }\end{array}$} \\
\hline
\end{tabular}




\section{Conclusion}

The resistance seam hardfacing is a proven method for thin layer hardfacing to reduce abrasive wear. With the method powders are welded in direct current flow on rotationally symmetrical components. Here a soft matrix material (NiCrBSi) has proven to hold hardfacing materials (WC-Co). Using the example of chain bucket bolts a third layer (NiCrBSi) was be applied to protect the bearings.

In metallographic can be seen that the WC-Co balls remain largely intact. Only smaller balls are dissolved in the NiCrBSi-matrix, a fine dispersion of the tungsten carbides occured. The connection of the layers to one another and to the base material is diffusion based with a dilution level of $D=1 \%$.

Economically, the method must be compared with thermal spraying. It turns out that the process does not require auxiliaries and additional plant technology. This offers advantages.

In future work, the process will continued to specialize in the direction of small parts.

In general the presented technology can be applied an rod and tubes. It can easily be integrated in any kind of production line.

\section{References}

[1] Fahrenwaldt, H. J., Schuler, V.: Praxiswissen Schweißtechnik, Vieweg Verlag, Wiesbaden, 2006.

[2] DIN EN 14700: Schweißzusätze - Schweißzusätze zum Hartauftragen, 2014

[3] DIN EN 657: Thermal spraying - Terminology, classification, 2003.

[4] Sitte, G., Keitel, S.: Rollennaht-Auftragschweißen - eine Alternative zum thermischen Spritzen hochbeanspruchter Oberflächen, Tagungsband UTSC, Düsseldorf, 1999.

[5] Bouaifi, B.,Günster, J., Schreiber, F.: Mikrostrukturelle Untersuchungen an wolframcarbidverstärkten Nickel- und Eisenbasislegierungen, Schweißen und Schneiden 49 (1997) 11, S. 858-866.

[6] Mathesius, H., Krömmer, W.: Praxis des thermischen Spritzens, DVS Media, Düsseldorf, 2014.

[7] DVS-Merkblatt 3211 Kostenbetrachtungen für die Prozesse des Elektronenstrahl- und Laser-strahlschweißens, 02/1998. 